\section{All-Carbon Carbodicarbene}

\section{Key words}

carbodicarbenes

bent allenes

carbon donors

gold complexes

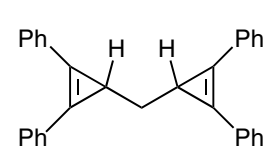

1

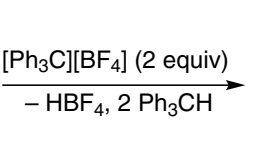
$-\mathrm{HBF}_{4}, 2 \mathrm{Ph}_{3} \mathrm{CH}$

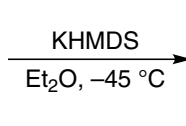

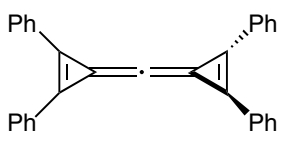<smiles>C(=C1C(c2ccccc2)=C1c1ccccc1)=C1C(=Cc2ccccc2)C1c1ccccc1</smiles>
$\mathrm{B}\left(\mathrm{C}_{6} \mathrm{~F}_{5}\right)_{3}$<smiles>[GeH3]</smiles>

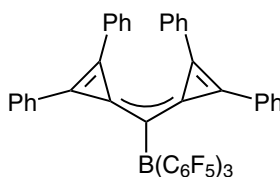

4<smiles>ClC(Cl)(Cl)C1=C(c2ccccc2)C1=C1C(c2ccccc2)=C1c1ccccc1</smiles>

5

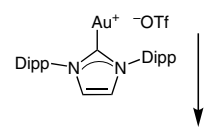

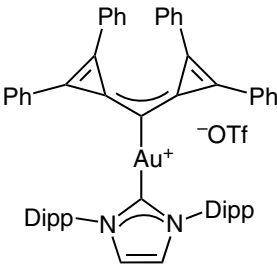

Significance: The authors present the first carbodicarbene stabilized by two cyclopropenylidenes. Compound $\mathbf{3}$ is made by deprotonation of the corresponding triafulvene cyclopropenium salt and is characterized by NMR at $-60^{\circ} \mathrm{C}$. The divalent electron-donating property of the center carbon on $\mathbf{3}$ is confirmed by generating main-group and transition-metal complexes.
Comment: A carbenoid carbon is usually stabilized by amino groups through charge delocalization. Herein the authors use a phenyl group to serve a similar purpose and the carbodicarbene, which is based solely on carbon without any heteroatom, is very impressive. The stable complexes 4-6 are all characterized by single-crystal X-ray diffraction. 